\title{
Differential Sensitivity of Human Fibroblasts and Endothelial Cells to Reactive Oxygen Metabolites
}

\author{
T. KRISTIINA AALTO AND KARI O. RAIVIO
}

Children's Hospital, University of Helsinki, SF-00290 Helsinki, Finland

\begin{abstract}
Reactive oxygen metabolites are implicated in tissue damage, which is often followed by fibrosis. Our aim was to evaluate the sensitivity of human fibroblasts, in comparison with umbilical vein endothelial cells, to two common reactive oxygen metabolites, to superoxide produced by hypoxanthine and xanthine oxidase, and to reagent hydrogen peroxide. Depletion of the prelabeled adenine nucleotide pool, which is a sensitive index of cell damage, was used as the basis for comparison. In the presence of hypoxanthine, xanthine oxidase caused a dosedependent nucleotide depletion, which was more pronounced in endothelial cells. After $4 \mathrm{~h}$ of exposure to 100 $\mu \mathrm{M}$ hypoxanthine and $80 \mathrm{mU} / \mathrm{mL}$ xanthine oxidase, fibroblasts retained $73 \pm 2 \%$ of their adenine nucleotides but endothelial cells retained only $11 \pm 2 \%$. Hydrogen peroxide also had a larger effect on endothelial cells; after exposure to $100 \mu \mathrm{M}$ for $30 \mathrm{~min}$, adenine nucleotides retained $36 \pm 26 \%$ of their initial radioactivity in endothelial cells but $76 \pm 8 \%$ in fibroblasts. We conclude that umbilical vein endothelial cells are inherently more sensitive to the harmful effects of reactive oxygen metabolites than are fetal skin fibroblasts. (Pediatr Res 32: 654-657, 1992)
\end{abstract}

\section{Abbreviations}

ROM, reactive oxygen metabolites $\mathrm{XO}$, xanthine oxidase

ROM have been implicated in cellular damage under many circumstances, for example, ischemia-reperfusion injury (1), hyperoxia (2), and inflammation (3, 4). In ischemia-perfusion injury, endothelial cells are the first target because of their localization in the vascular wall, and the first signs of damage have been demonstrated in these cells $(5,6)$. In chronic exposure to hyperoxia, production of ROM increases (7), and the pulmonary vascular bed may gradually disappear and be replaced by fibrosis $(8,9)$. ROM-induced diseases are frequent, especially in the neonatal period $(10,11)$.

Recently we have shown that when cultured human endothelial cells are exposed to XO (EC 1.1.3.22) and hypoxanthine, cellular adenine nucleotides are depleted (12). ATP depletion is a more sensitive indicator of cell damage than, for example, morphologic criteria or the release of radioactive chromium (13, 14 ), and the damage may be reversible. In the present study, our aim was to use this indicator to explore possible differences between human fibroblasts and umbilical vein endothelial cells in their sensitivity to extracellular oxidants, generated at concentrations relevant to human pathology.

Received March 23, 1992; accepted July 2, 1992

Correspondence: Kristiina Aalto, M.D., Children's Hospital, University of Helsinki, Stenbäckinkatu 11, SF-00290 Helsinki, Finland.

Supported by the Academy of Finland, the Sohlberg Foundation, and the J. von Wendt Foundation.

\section{MATERIALS AND METHODS}

Cell culture and labeling of adenine nucleotides. Fibroblasts derived from mid-trimester human fetal skin samples or amniotic fluid samples were cultured in Ham's F-10 medium (Gibco Europe, Paisley, UK) containing penicillin $(100 \mathrm{U} / \mathrm{mL})$, streptomycin $(100 \mu \mathrm{g} / \mathrm{mL}$, Gibco), L-glutamine (2 mM, Orion Diagnostica, Espoo, Finland), and $10 \%$ FCS (Gibco). The identity of the fibroblasts was confirmed by morphologic appearance. For experiments, cells were transferred to multiwell dishes (Nunc, Roskilde, Denmark) and grown to confluency.

Human umbilical vein endothelial cells were cultured by the method of Jaffe et al. (15) with modifications previously described (12). They were identified as endothelial cells by the typical cobblestone pattern in phase contrast microscopy, and by the presence of factor VIII antigen assessed by indirect immunofluorescence; over $90 \%$ of the cells stained positively. For experiments, cells were grown to confluency in gelatin-coated multiwell dishes in F-10 medium with serum.

Both fibroblasts and endothelial cells were prelabeled for 16$18 \mathrm{~h}$ with ${ }^{14} \mathrm{C}$-adenine (sp act $51-55 \mathrm{mCi} / \mathrm{mmol}$; Amersham International, Amersham, UK), final concentration $0.1 \mathrm{mM}$, in F-10 medium with serum. The cells were then washed three times with purine-free RPMI 1640 medium (Gibco) without serum. The cells accumulate radioactivity mainly in adenine nucleotides; an average of $50 \%$ of the ATP pool is labeled (12, 16). Previously we have shown that there is no difference between the metabolism of ${ }^{14} \mathrm{C}$-labeled and unlabeled nucleotides in cultured cells (17, unpublished observations).

Oxidant exposure. After prelabeling and washing the plates, RPMI 1640 medium was added to each well followed by XO (Boehringer Mannheim, Penzberg, Germany) and hypoxanthine (Sigma Chemical Co., St. Louis, MO) at the concentrations indicated. To counteract the known proteolytic activity in $\mathrm{XO}$ preparations (18), $5 \mathrm{mg} / \mathrm{mL}$ soybean trypsin inhibitor (Sigma) was also present in the medium. Hydrogen peroxide (Merck AG, Darmstadt, Germany) was added to final concentrations of 20 or $100 \mu \mathrm{M}$.

After incubations for up to $4 \mathrm{~h}$, the medium was removed and frozen. The cells were extracted twice with $0.42 \mathrm{~N}$ perchloric acid, and the combined extracts were stored at $-20^{\circ} \mathrm{C}$ until analysis.

Analysis of purine compounds. Aliquots of the culture media were spotted on cellulose thin-layer chromatogram sheets (Eastman Kodak Company, Rochester, NY), and the radioactivities in total nucleotides, adenosine, inosine, hypoxanthine, xanthine, and uric acid were measured as described (12) with butanol:methanol:water:ammonia $(60: 20: 20: 1)$ as solvent. Cell extracts were neutralized and the purine nucleotides were separated by thin-layer chromatography on polyethyleneimine cellulose (Macherey-Nagel, Düren, Germany) using a formate gradient, then the radioactivities in the purine nucleotides were determined with a liquid scintillation counter (12). In some experiments, the radioactivities in the acid-insoluble nucleic acid fractions were also counted. 
ATP concentrations in neutralized perchloric acid cell extracts were measured also with liquid chromatography, using a method modified from that described by Stocchi et al. (19, 20). A Shimadzu LC 6A liquid chromatograph was used with a reversed phase column (Ultra Techsphere C18, HPLC Technology Ltd., Macclesfield, UK) and UV detector set at $254 \mathrm{~nm}$. Buffer A $(0.1$ $\mathrm{M} \mathrm{KH}_{2} \mathrm{PO}_{4}, \mathrm{pH} 6.0$, containing $8 \mathrm{mM}$ tetrabutylammonium hydrogen sulfate) was run at $1.5 \mathrm{~mL} / \mathrm{min}$ for $2.5 \mathrm{~min}$, followed by a linear increase over $12.5 \mathrm{~min}$ to $100 \%$ buffer B (buffer A with $30 \%$ of methanol), and continued for $5 \mathrm{~min}$. ATP was identified and quantified by the retention time and peak area compared with the known standard, calibrated by spectrophotometry.

Expression of results and statistical methods. As previously shown for endothelial cells (12), radioactivity in nucleic acids or in guanine nucleotides in fibroblasts labeled with ${ }^{14} \mathrm{C}$-adenine is small (less than $10 \%$ of total cpm incorporated) and does not change significantly upon exposure to ROM. Therefore, the results are expressed as percentage of distribution of radioactivity between the perchloric acid-soluble compounds of interest in cells (adenine nucleotides) and medium (catabolic products: hypoxanthine, xanthine, uric acid; and nucleotides).

Protein concentration was measured spectrophotometrically with the micromethod of Bradford (21) using a commercial kit (Bio-Rad Laboratories, Richmond, CA).

All experiments were performed in duplicate at least twice. Comparisons between two groups were performed by the nonparametric Mann-Whitney U-test. Results are expressed as means \pm SD.

\section{RESULTS}

Effect of exogenous superoxide. When fibroblasts were incubated in serum-free medium with $80 \mathrm{mU} / \mathrm{mL} \mathrm{XO}$ and $100 \mu \mathrm{M}$ hypoxanthine for $4 \mathrm{~h}$, cellular nucleotide levels decreased to 73 $\pm 2 \%$ of initial cpm, compared with $85 \pm 4 \%$ in control cells (Fig. 1). There was an equivalent increase in catabolic products (hypoxanthine, xanthine, and uric acid) in the medium but no detectable release of intact nucleotides. Endothelial cells had a slightly higher basal adenine nucleotide turnover in serum-free medium, as shown by the proportion of radioactivity in nucleotides versus catabolic products in control cells (Figs. 1 and 3 ).

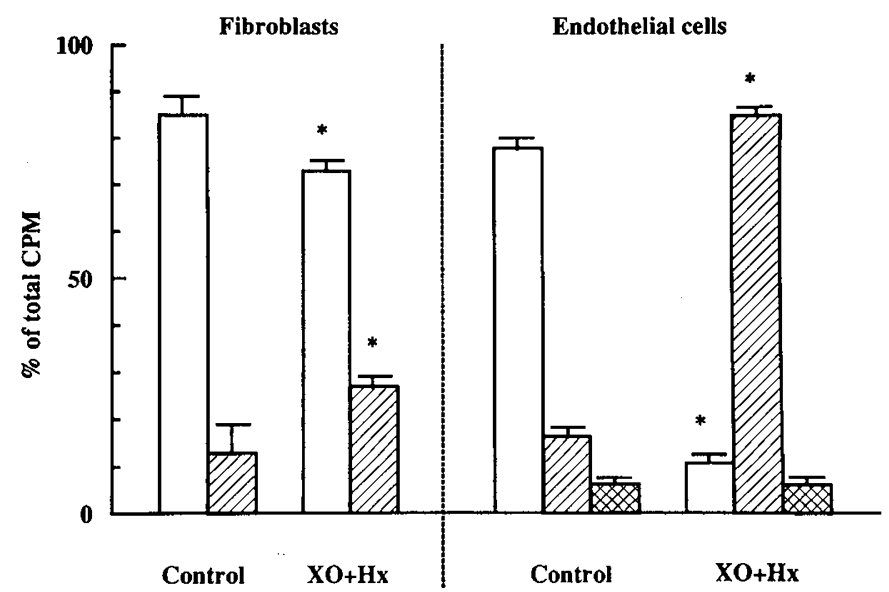

Fig. 1. Adenine nucleotide depletion from fibroblasts and endothelial cells prelabeled with ${ }^{14} \mathrm{C}$-adenine, washed, and incubated with hypoxanthine $(H x, 100 \mu \mathrm{M}), \mathrm{XO}(80 \mathrm{mU} / \mathrm{mL})$, and $5 \mathrm{mg} / \mathrm{mL}$ soybean trypsin inhibitor in serum-free medium for $4 \mathrm{~h}$. Open bars indicate cellular adenine nucleotides; hatched bars indicate the sum of catabolic products (hypoxanthine, xanthine, uric acid) in the medium; cross-hatched bars indicate the sum of nucleotides in the medium. Results are expressed as percentage of total soluble radioactivity in cells plus medium (means \pm $\mathrm{SD}$ ). Asterisks indicate $p<0.05$ compared with control (Mann-Whitney U test, $n=4)$.
There was also a small but consistent release of labeled nucleotides, which was not seen in fibroblasts. After exposure to XO and hypoxanthine, endothelial cell adenine nucleotides were nearly totally depleted $(11 \pm 2 \%$ of total $\mathrm{cpm})$ and a corresponding increase in catabolic products was seen $(84 \pm 1 \%$ of total cpm) (Fig. 1). ATP concentrations in fibroblasts, analyzed with HPLC, showed a decrease of $19 \%$ compared with control cells (18 $\pm 4 \mathrm{nmol}$ ATP/mg protein), which is similar to the decrease of radioactive ATP (Fig. 2). Endothelial cell ATP concentrations decreased by $81 \%$ under these conditions (Fig. 2), and control cells contained $8 \pm 1 \mathrm{nmol} \mathrm{ATP} / \mathrm{mg}$ protein.

To explore the dose-response to $\mathrm{XO}$, cells were incubated with increasing concentrations of $\mathrm{XO}$ and $100 \mu \mathrm{M}$ hypoxanthine. The difference in adenine nucleotide depletion between fibroblasts and endothelial cells became significant at the concentration of $40 \mathrm{mU} / \mathrm{mL}$ of XO (Fig. 3).

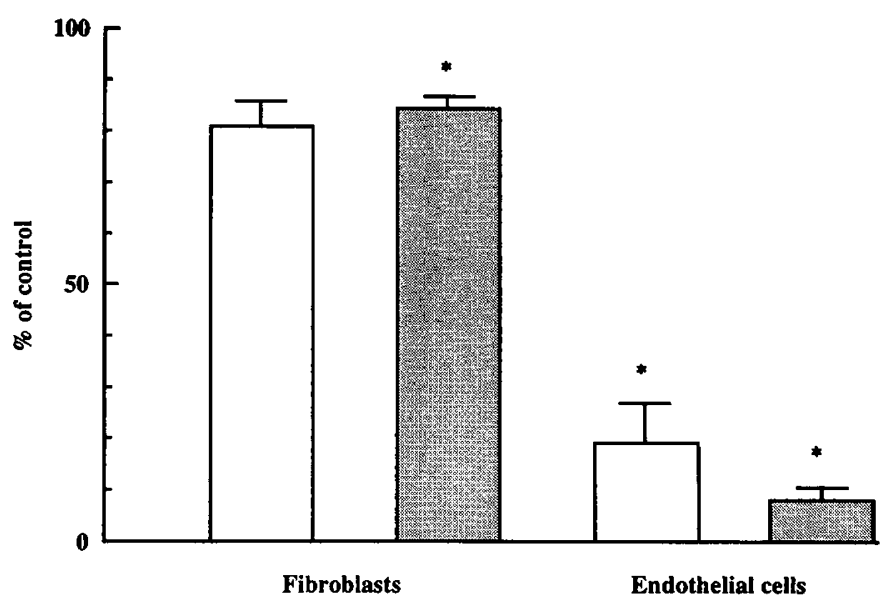

Fig. 2. Decrease in total ATP concentrations, measured with liquid chromatography (open bars), or in radioactive ATP, counted after separation of nucleotides with thin-layer chromatography (gray bars), in fibroblasts and endothelial cells after incubation of prelabeled $\left({ }^{14} \mathrm{C}\right.$ adenine) cells with hypoxanthine $(100 \mu \mathrm{M}), \mathrm{XO}(80 \mathrm{mU} / \mathrm{mL})$, and 5 $\mathrm{mg} / \mathrm{mL}$ soybean trypsin inhibitor in serum-free medium for $4 \mathrm{~h}$. Results are expressed as percentage of control cell ATP concentrations (means $\pm \mathrm{SD}$ ). For control values, see Results. Asterisks indicate $p<0.05$ compared with control (Mann-Whitney U test, $n=4$ ).

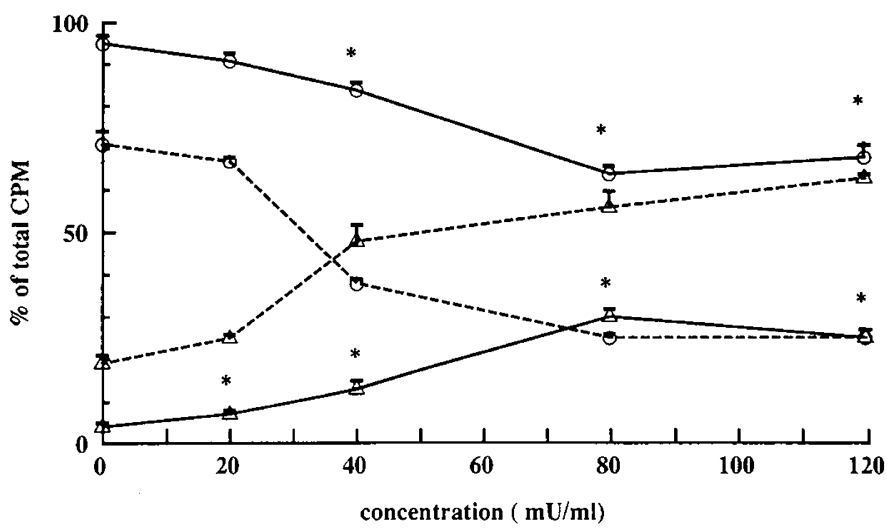

Fig. 3. Nucleotide depletion from prelabeled $\left({ }^{14} \mathrm{C}\right.$-adenine $)$ fibroblasts (solid lines) and endothelial cells (dashed lines) incubated with varying concentrations of $\mathrm{XO}$ in the presence of $100 \mu \mathrm{M}$ hypoxanthine and 5 $\mathrm{mg} / \mathrm{mL}$ soybean trypsin inhibitor in serum-free medium for $1 \mathrm{~h}$. Circles indicate the sum of adenine nucleotides in the cells; triangles indicate the sum of catabolic products in the medium. Results are expressed as percentage of total soluble radioactivity in cells plus medium (means \pm $\mathrm{SD}$ ). Asterisks indicate $p<0.05$ (Mann-Whitney $\mathrm{U}$ test, $n=4$ ) comparing the change in relation to basal nucleotide turnover $(0 \mathrm{mU} / \mathrm{mL} \mathrm{XO})$ between fibroblasts and endothelial cells. 
Effect of hydrogen peroxide. After incubation for $30 \mathrm{~min}$ without additions, adenine nucleotides retained $92 \pm 4 \%$ of total radioactivity in fibroblasts and $80 \pm 4 \%$ in endothelial cells. Hydrogen peroxide at a concentration of $20 \mu \mathrm{M}$ had no effect on fibroblasts but caused significant nucleotide depletion after $30 \mathrm{~min}$ in endothelial cells (Fig. 4). At $100 \mu$ M hydrogen peroxide after $30 \mathrm{~min}$, there was a decrease to $76 \pm 8 \%$ of total $\mathrm{cpm}$ in radioactive adenine nucleotides in fibroblasts but a decrease to $36 \pm 26 \%$ in endothelial cells (Fig. 5).

\section{DISCUSSION}

We have previously shown that when human umbilical vein endothelial cells are exposed to XO and hypoxanthine, their adenine nucleotides are depleted (12). This is due partly to leakage of nucleotides through the cell membrane and partly to intracellular catabolism (20). Nucleotide depletion is a sensitive indicator of cell damage $(13,14)$, which is not necessarily irreversible. Our experimental model is relevant to human pathophysiologic situations in which ROM are generated extracellularly, e.g. in inflammation by phagocytic cells or in ischemiareperfusion injury, when both hypoxanthine (22) and XO (23) appear in plasma in concentrations similar to those used in our experiments.

It is not unexpected that fibroblasts in vitro tolerate ROM better than endothelial cells, because in vivo the former replace the latter in tissues damaged by ischemia-reperfusion. Several studies in intact animals and cultured cells have demonstrated

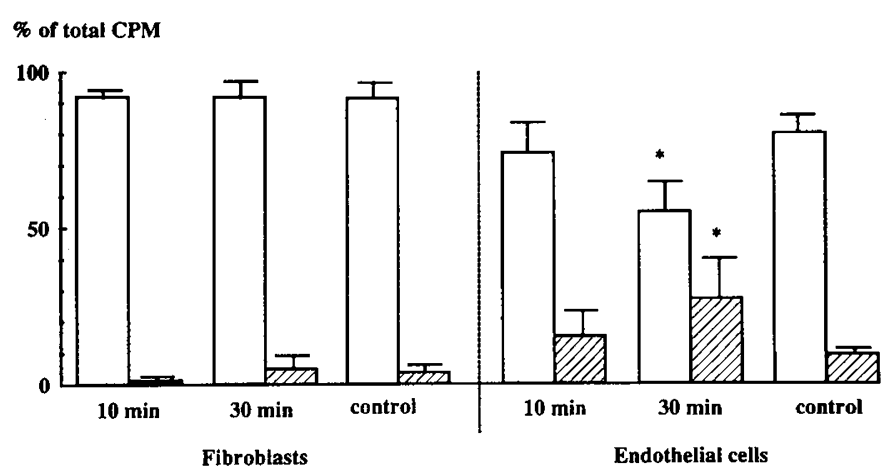

Fig. 4. Adenine nucleotide depletion from cells prelabeled with ${ }^{14} \mathrm{C}$ adenine, washed, and incubated with $20 \mu \mathrm{M} \mathrm{H}_{2} \mathrm{O}_{2}$ in serum-free medium for 10 or $30 \mathrm{~min}$. Open bars indicate cellular adenine nucleotides; hatched hars indicate the sum of catabolic products (hypoxanthine, xanthine, uric acid) in the medium. Results are expressed as percentage of total soluble radioactivity in cells plus medium (means \pm SD). Asterisks indicate $p<0.05$ (Mann-Whitney $\mathrm{U}$ test, $n=4$ ) compared with control (incubation for $30 \mathrm{~min}$ without $\mathrm{H}_{2} \mathrm{O}_{2}$ ).

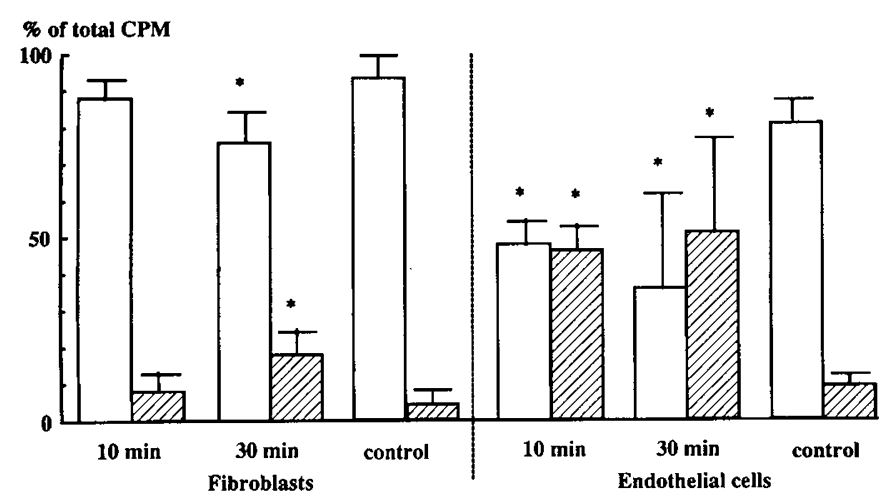

Fig. 5. Adenine nucleotide depletion from cells prelabeled with ${ }^{14} \mathrm{C}$ adenine, washed, and incubated with $100 \mu \mathrm{M} \mathrm{H}_{2} \mathrm{O}_{2}$ in serum-free medium for 10 or $30 \mathrm{~min}$. Expression of results and symbols are as in Figure 4. this superior tolerance, although less sensitive methods to indicate cell injury have been used $(24,25)$. In ischemia-perfusion injury in vivo, endothelial cells could be more susceptible because of their location in the front line, whereas fibroblasts would remain viable because they are further removed from the vascular wall. Our data indicate that the differential susceptibility is not due to spatial factors but is inherent to the cells.

Our results suggest that both the superoxide radical, generated by $\mathrm{XO}$ acting on hypoxanthine, and hydrogen peroxide have a more profound effect on cellular nucleotides in umbilical vein endothelial cells compared with fetal skin fibroblasts. In comparing the effects of $\mathrm{XO}$ and hypoxanthine on the two cell types, it seems that there is a release of intact nucleotides from endothelial cells but not from fibroblasts (Fig. 1). However, when hydrogen peroxide was present in the medium, there was no significant release of intact nucleotides from either cell type. Even though nucleotide efflux might, to some extent, be masked by the action of ecto-5'-nucleotidases (26), it is more likely that the depletion of adenine nucleotides is due to intracellular catabolism (27). We have previously shown that when ecto-5'-nucleotidase is inhibited, superoxide causes leakage of nucleotides in endothelial cells, indicating membrane damage, but hydrogen peroxide does not (20). The present results suggest that fibroblasts are even less prone to membrane damage.

Our aim was not to explore the mechanisms of the greater tolerance of fibroblasts to damage by ROM. Several possibilities exist, including differences in membrane structure or in endogenous antioxidant defense mechanisms $(25,28)$. In vivo, endothelial cells have been shown to suffer morphologic damage early in the course of tissue injury $(5,29,30)$. The more durable fibroblasts would remain undamaged and be able to proliferate in the reparative stage of the process, producing residual fibrosis.

Acknowledgments. The authors thank Sari Lindén for skillful technical assistance.

\section{REFERENCES}

1. McCord JM 1985 Oxygen-derived free radicals in postischemic tissue injury. N Engl J Med 312:159-163

2. Freeman BA, Crapo JD 1982 Biology of disease. Free radicals and tissue injury. Lab Invest 47:412-426

3. McCord JM 1983 The superoxide free radical: its biochemistry and pathophysiology. Surgery 94:412-414

4. Ward PA, Warren JS, Johnson KJ 1988 Oxygen radicals, inflammation, and tissue injury. Free Radic Biol Med 5:403-408

5. Grosso MA, Brown JM, Viders DE, Mulvin DW, Banerjee A, Velasco SE, Repine JE, Harken AH 1989 Xanthine oxidase-derived oxygen radicals induce pulmonary edema via direct endothelial cell injury. J Surg Res 46:355-360

6. Ratych RE, Chiknyiska RS, Bulkley GB 1987 The primary localization of free radical generation after anoxia/reoxygenation in isolated endothelial cells. Surgery 102:122-131

7. Freeman BA, Topolosky MK, Crapo JD 1982 Hyperoxia increases oxygen radical production in rat lung homogenates. Arch Biochem Biophys 216:477-484

8. Johnson KJ, Fantone III JC, Ward PA 1981 In vivo damage of rat lungs by oxygen metabolites. J Clin Invest 67:983-993

9. Crapo JD 1986 Morphologic changes in pulmonary oxygen toxicity. Annu Rev Physiol 48:721-731

10. Saugstad OD 1990 Oxygen toxicity in the neonatal period. Acta Paediatr Scand 79:881-892

11. Frank L, Bucher JR, Roberts RJ 1978 Oxygen toxicity in neonatal and adult animals of various species. J Appl Physiol 45:699-704

12. Aalto TK, Raivio KO 1990 Adenine nucleotide depletion from endothelial cells exposed to xanthine oxidase. Am J Physiol 259:C883-C888

13. Ager A, Gordon JL 1984 Differential effects of hydrogen peroxide on indices of endothelial cell function. J Exp Med 159:592-603

14. Andreoli SP, Baehner RL, Bergstein JM 1985 In vitro detection of endothelial cell damage using 2-deoxy-D- ${ }^{3} \mathrm{H}$-glucose: comparison with chromium 51 , ${ }^{3} \mathrm{H}$-leucine, ${ }^{3} \mathrm{H}$-adenine, and lactate dehydrogenase. J Lab Clin Med 106:253261

15. Jaffe EA, Nachman RL, Becker CG, Minick CR 1973 Culture of human endothelial cells derived from umbilical veins. J Clin Invest 52:2745-2756

16. Andreoli SP 1989 Mechanisms of endothelial cell ATP depletion after oxidant injury. Pediatr Res 25:97-101

17. Matsumoto SS, Raivio KO, Seegmiller JE 1979 Adenine nucleotide degradation during energy depletion in human lymphoblasts. J Biol Chem 254:89568962 
18. Ager A, Wenham DJ, Gordon JL 1984 Stimulation of endothelial cells by protease activity in commercial preparations of xanthine oxidase. Thromb Res 35:43-52

19. Stocchi V, Cucchiarini L, Canestrani F, Piacentini MP, Fornaini G 1987 A very fast ion-pair reversed-phase HPLC method for the separation of the most significant nucleotides and their degradation products in human red blood cells. Anal Biochem 167:181-190

20. Aalto TK, Raivio KO 199? Mechanisms of adenine nucleotide depletion from endothelial cells exposed to reactive oxygen metabolites. Free Radic Biol Med (in press)

21. Bradford MM $1976 \mathrm{~A}$ rapid and sensitive method for the quantitation of microgram quantities of protein utilizing the principle of protein-dye binding. Anal Biochem 72:248-254

22. Harkness RA 1988 Hypoxanthine, xanthine and uridine in body fluids, indicators of ATP depletion. J Chromatogr 429:255-278

23. Friedl HP, Smith DJ, Till GO, Thompson PD, Louis SD, Ward PA 1990 Ischemia-reperfusion in humans. Am J Pathol 136:491-495

24. Michiels C, Toussaint O, Remacle J 1990 Comparative study of oxygen toxicity in human fibroblasts and endothelial cells. J Cell Physiol 144:295-302
25. Mickle DAG, Li RK, Weisel RD, Tumiati LC, Wu TW 1990 Water-soluble antioxidant specificity against free radical injury using cultured human ventricular myocytes and fibroblasts and saphenous vein endothelial cells. J Mol Cell Cardiol 22:1297-1304

26. Pearson JD, Gordon JL 1985 Nucleotide metabolism by endothelium. Annu Rev Physiol 47:617-627

27. Schraufstatter IU, Hyslop PA, Hinshaw DB, Spragg RG, Sklar LA, Cochrane CG 1986 Hydrogen peroxide-induced injury of cells and its prevention by inhibitors of poly(ADP-ribose) polymerase. Proc Natl Acad Sci USA 83:4908-4912

28. Bishop CT, Mirza Z, Crapo JD, Freeman BA 1985 Free radical damages to cultured porcine aortic endothelial cells and lung fibroblasts: modulation by culture conditions. In Vitro 21:229-236

29. Suval WD, Duran WN, Boric MP, Hobson RW, Berendsen PB, Ritter AB 1987 Microvascular transport and endothelial cell alterations preceding skeletal muscle damage in ischemia and reperfusion injury. Am J Surg 154:211-218

30. Kistler GS, Caldwell PRB, Weibel ER 1967 Development of fine structural damage to alveolar and lining cells in oxygen-poisoned rat lungs. $J$ Cell Biol $33: 605-628$ 